\title{
Constitutional change and inequality in Scotland
}

\author{
David Comerford \\ Division of Economics \\ University of Stirling \\ David Eiser \\ Division of Economics \\ University of Stirling
}

\begin{abstract}
What scope does a sub-national economy have to affect the level of inequality? Does a policy menu consistent with the theories of fiscal federalism provide for an ability to affect inequality measures, or does this ability require the powers of a nation state? In this paper we discuss these questions in the context of the debate around the Scottish independence referendum, in which inequality has played a prominent role, and ask whether independence, further devolution, or simply different policies under the current constitutional framework are capable of helping Scotland transition to a less unequal income distribution. We provide a series of estimates of the impact of different policy choices upon inequality in Scotland, and discuss inequality reduction in the context of different constitutional options.
\end{abstract}

JEL Codes: H2, H3, R1, R5 


\section{Introduction}

'This level of inequality offends the very basis of a good society'

Alex Salmond, speech to the SNP Party Conference, October 2013

Inequality is at the centre of the debate on Scottish independence. In making a case for independence, the Scottish Government (2013) argues: 'Scotland is currently part of a UK economic model and society which is one of the most unequal in the OECD. Inequality within the UK has increased in recent decades. Such patterns of inequality will continue to have a negative impact on growth and prosperity over the long-term'. Independence, it is argued, would give access to the fiscal levers necessary to address inequality ${ }^{1}$.

The purpose of this paper is to analyse the question of the extent to which the government of a small open country or semi-autonomous region can achieve a different level of income inequality from the wider economy of which it is part. We consider the feasibility of the Scottish Government securing a lower level of inequality through redistribution and fiscal policy. The paper examines the effectiveness of various fiscal levers, some of which are already within the control of the Scottish Government, and others which would only be available under enhanced devolution or independence. We consider the constraints that the Scottish Government might face in exercising these fiscal levers, either as a fully independent country, or as a devolved administration within the UK.

Many proponents of independence have emphasised the current level of inequality in Scotland and in the UK, and the possibility of an independent Scotland being able to reduce this level, as a primary reason for their support of independence. Section 2 documents the current levels of inequality in Scotland and in the UK relative to international comparisons. The Nordic countries in particular have relatively low inequality, driven in part by having a more redistributive tax and benefit system. The Nordic countries are often cited as evidence of what an independent Scotland could achieve (see for example the 'Common Weal' project' described in Danson and Trebeck, 2013). The drivers of inequality include a mix of economic (technological change, globalisation, labour market participation) and societal (changes to household structure and family and living arrangements) that often transcend national boundaries and cannot easily be manipulated by governments. However, it is clear that independent countries do have some ability to influence income inequality. Stiglitz (2013) argues that inequality is effectively a policy choice, that 'inequality is a product of political and not merely macroeconomic forces', and that 'it is not true that inequality is an inevitable byproduct of globalisation'.

But would the Scottish Government be able to influence the level of inequality if it remained within the UK, albeit with some set of additional fiscal powers from those that it currently has? Traditional theories of fiscal federalism propose that redistributive policy levers should be reserved to the central government, since efforts at redistribution at sub-national level will be undermined by the mobility of workers. This is consistent with the Scotland Act 2012, which devolves to the Scottish Government the power to vary income tax proportionately across rates, but not to vary specific tax

\footnotetext{
${ }^{1}$ The analysis in this paper deals specifically with inequality of income; throughout the paper, the word inequality can be inferred to imply income inequality.

${ }^{2} \mathrm{http}$ ://scottishcommonweal.org/what-is-the-common-weal-project/
} 
rates or thresholds, or to change tax credits or benefits. In Section 3 we discuss the crucial role played by factor mobility in redistributive policy. Whilst independent governments may be more able, in the long run, to influence the level of inequality relative to a devolved government within a wider union, the price of this ability is that some barriers to mobility would accompany independence. Conversely, in a decentralised administrative region of a larger state, and probably also in the early days of an independent state, factor mobility might be hypothesised to act as a significant constraint in implementing radically differential policy. The fiscal federalism literature explicitly relates mobility and preference heterogeneity both to the sustainability of, and the level of desire for, redistributive policy.

There is some evidence that the Scottish electorate has more social democratic preferences than the electorate of the rest of the UK (rUK) i.e. there may be preference heterogeneity at a geographic level within the UK. This evidence is most clear in voting patterns, with Scots traditionally voting for Conservatives in much smaller numbers than in rUK. These preference differences may motivate differential redistributive policy across the countries of the UK, but such differential policy has obvious implications for the incentives to relocate, and the propensity to move becomes a crucial factor in the sustainability of these policy differences. The evidence presented in Sections 2 and 3 can be summarised as saying that independence, if it leads to a decline in mobility, may well (eventually) lead to the ability to implement and sustain more redistributive policy. But how feasible is greater redistributive policy in the context of enhanced devolution, since in this case Scotland will still be part of the integrated and mobile labour and capital markets of the UK? Section 4 presents an outline of some of the specific proposals that have been made for Scotland operating as a decentralised sub-national unit in addition to the binary choice between status quo and full independence on the table at the referendum. These alternatives offer a number of different models of fiscal devolution, each bringing a particular set of policy levers within the autonomy of the Scottish Government.

Sections 5 and 6 outline the methods and results of the analysis that we conduct. We consider the extent to which Scotland would be able to achieve a different level of income inequality to rUK under a variety of different constitutional scenarios. We ask which policy levers are likely to be the most effective in influencing inequality, and the level of political and economic constraints that are likely to exist in operating these levers. The analysis is undertaken using a household level model of incomes, taxes and benefits in Scotland and, given the importance of mobility considerations, incorporates the possible behavioural responses of migration and labour supply induced by policy changes. We find that the policy levers available to an independent Scotland would give it greater flexibility to influence the income distribution than it has currently, but that fiscal policy alone is not sufficient to close Scotland's inequality gap with comparator Nordic countries.

\section{Swimming against the tide: trends in inequality and the role of policy}

The UK is ranked $7^{\text {th }}$ most unequal of 35 OECD countries in relation to net income inequality (inequality based on market incomes adjusted by taxes and benefits). Inequality in Scotland is lower than it is in the UK as a whole. This is because inequality is particularly high in London (Stewart, 2011, Bell and Eiser, 2013). Net income inequality in Scotland is roughly equivalent to the median 
level of inequality among the OECD countries, but inequality is higher in Scotland than it is in the Nordic countries that are often seen as operating the type of social-democratic model that an independent Scotland might wish to follow (Figure 1). Measured by the GINI coefficient, inequality in Scotland is around five percentage points higher than it is in the Nordic countries, and this holds true regardless of whether we look at the entire population or restrict analysis to the working age population.

Figure 1: Net income inequality in OECD countries, 2010

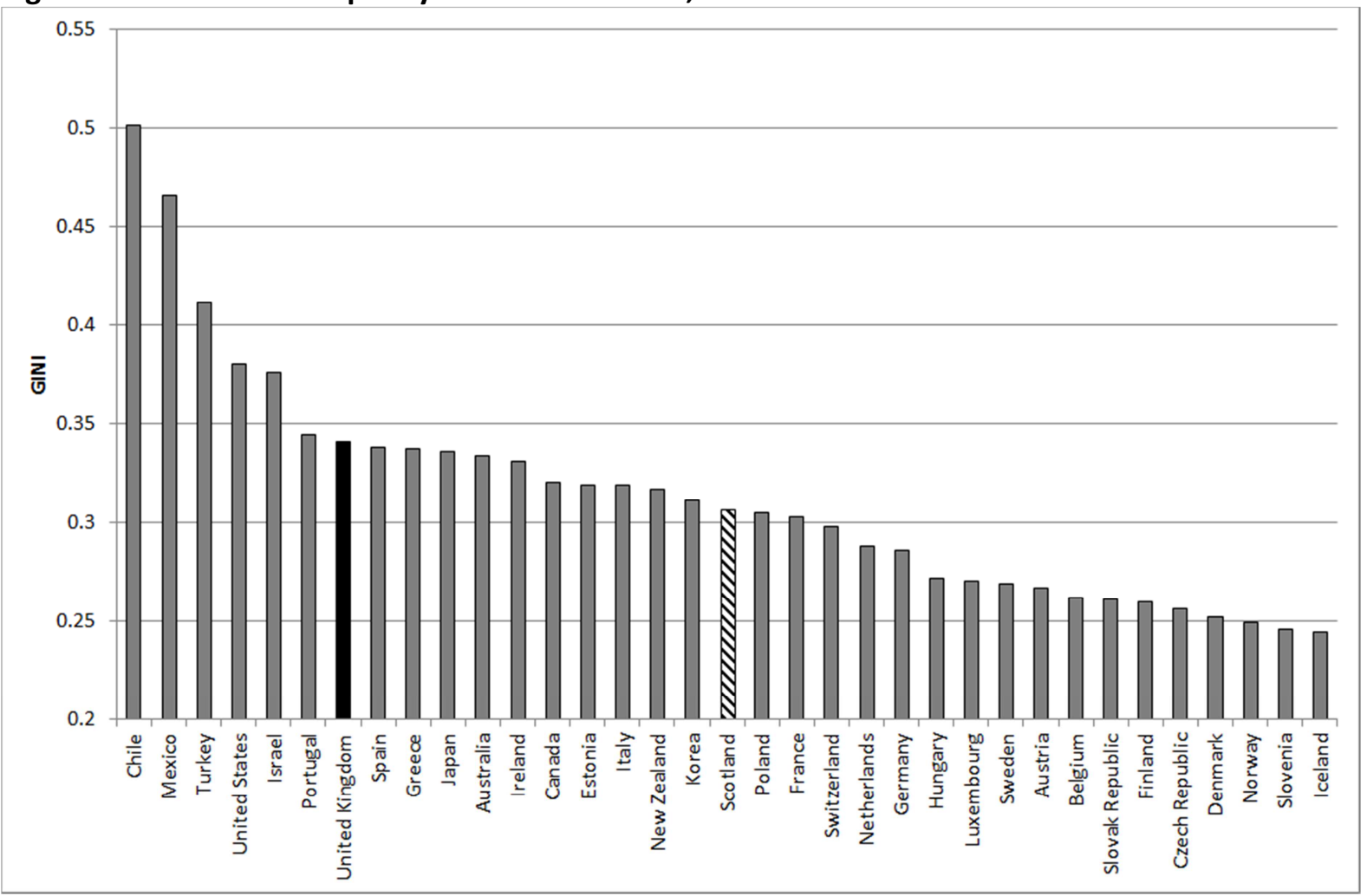

Source: OECD, HBAI. Figure shows GINI coefficient for working age population

To what extent is a lower level of income inequality a policy choice, achievable through fiscal levers? Figure 2 compares market (i.e. pre-tax and benefit) income inequality and net (post-tax and benefit) income inequality in a selection of OECD countries. The gap between market income inequality and net income inequality is the level of redistribution. Figure 2 shows that the level of net income inequality is more dispersed across countries than the level of market income inequality, supporting the contention that policy choices within a country are effective at influencing the level of net income inequality.

In the UK, taxes and social transfers have the effect of reducing the market income GINI coefficient by 13 percentage points, indicating that the UK tax/ benefit system is slightly more redistributive than for the OECD as a whole (where the effect of taxes and social transfers is to reduce the market income GINI coefficient by 12 percentage points). The Nordic countries have lower market income inequality than the UK, but their tax and benefit systems are also slightly more redistributive, reducing the market income GINI coefficient by 13, 14, and 15 percentage points in Norway, Denmark, and Finland respectively (Sweden=12). Market income is not entirely exogenous of course, as higher levels of redistribution are likely to lead to a reduction in higher incomes given behavioural responses to taxation. As well as influencing inequality through redistributive policy, Governments 
can also of course seek to influence market income inequality directly, through labour market regulation and industrial policy. In this paper however we focus on the role for fiscal policy.

Figure 2 Market and net income inequality, OECD countries 2010

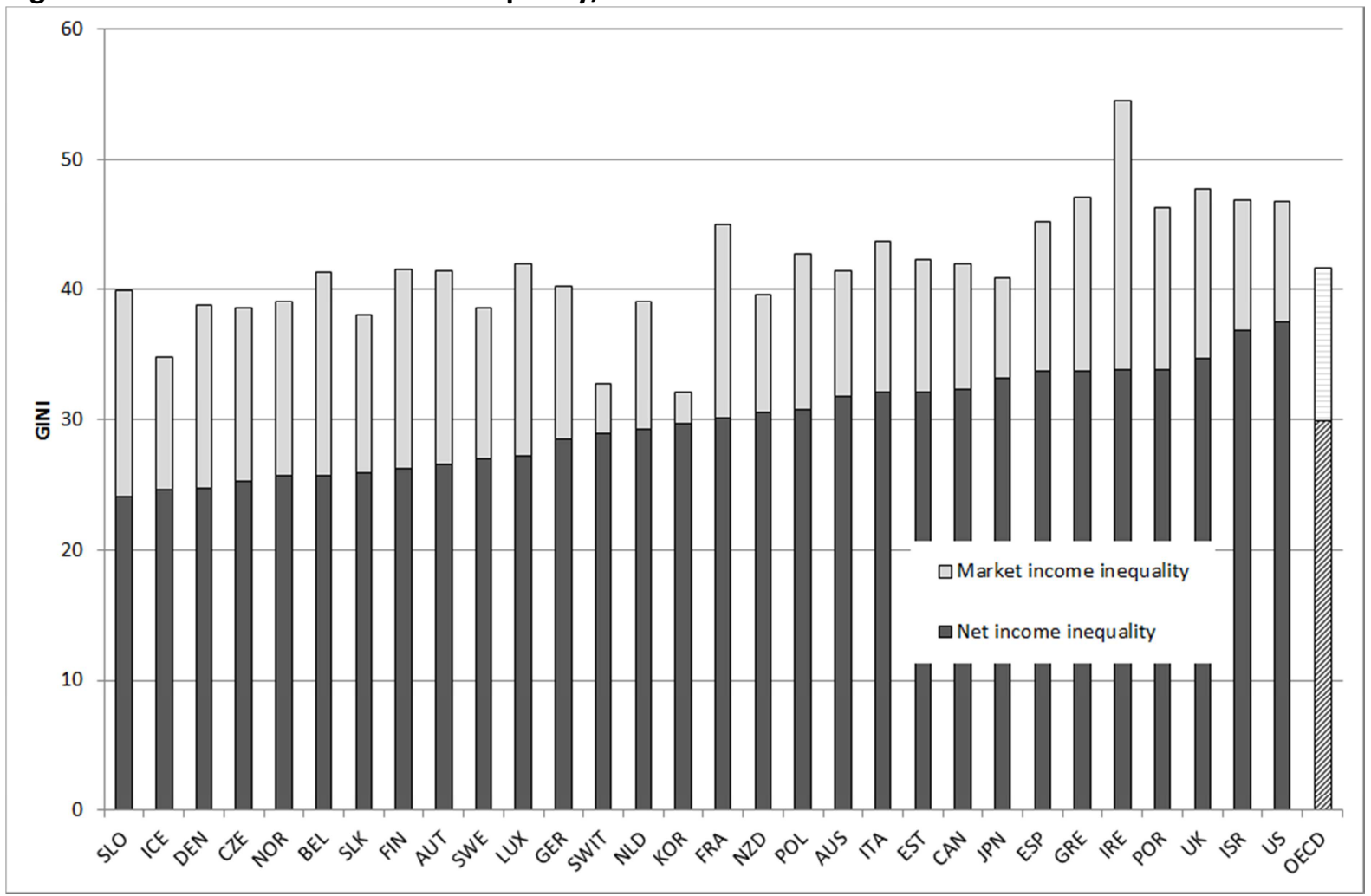

Source: OECD. Note: inequality of income among working age population

One would expect a positive link between levels of market income inequality and redistribution even in the absence of any conscious policy effort to counter inequality trends: because of the progressivity built into tax-benefit systems, a more dispersed market income 'automatically' strengthens the equalising effect of a given policy. Figure 3 plots the level of redistribution against market income inequality for OECD countries, and reveals evidence of the positive relationship that one would expect. It shows that some countries - including Slovenia, Denmark and Belgium - have relatively high levels of redistribution conditional on their levels of market income inequality, whilst others -notably including the US - have a relatively low level of redistribution conditional on market income inequality. The level of redistribution in the UK, although slightly above the OECD average, is broadly where we might expect it to be, given the UK's relatively high levels of market income inequality and the average level of redistribution in OECD countries ${ }^{3}$.

Summarising the information in Figures 2 and 3, we can say that the UK has a slightly higher level of redistribution than the OECD average, although the level of redistribution in the UK is not particularly high given its higher level of market income inequality, which should, ceteris paribus, result in higher redistribution for a given policy. However, even if the UK's tax and benefit system reduced market income inequality by an equivalent amount as it does in Denmark or Finland (where redistribution reduces the market income GINI by 14 and 15 percentage points respectively,

\footnotetext{
${ }^{3}$ Figures 2 and 3 show income inequality for the working age population; the UK is slightly less unequal, relative to other OECD countries, if inequality is measured across the entire population.
} 
compared to 13 percentage points in the UK), then the UK's level of net income inequality would remain higher than it is in these countries. Put another way, for the UK to reduce its level of net income inequality to Nordic levels entirely through taxes and transfers, then it would have to do so by having a much more redistributive fiscal system than these countries do (although, as noted above, higher redistribution is also likely to reduce market income inequality which is not entirely exogenous).

Figure 3: Relationship between market income inequality and redistribution for OECD countries

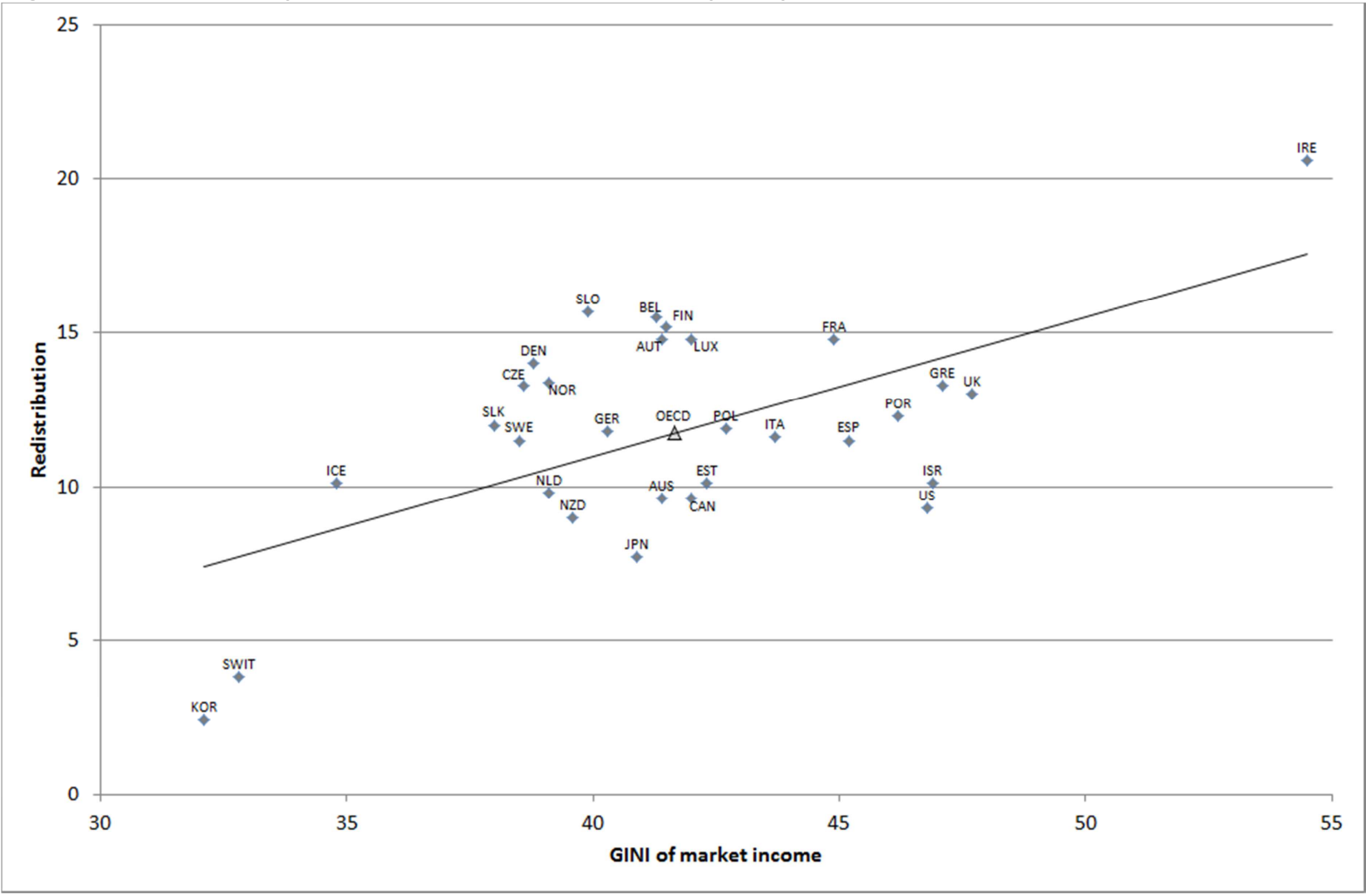

Source: $O E C D$

Inequality has been rising in most OECD countries for the past few decades (OECD, 2011). Inequality in the UK increased significantly during the 1980s and 1990s but has since been rising at a much slower rate (Cribb, et al., 2012). Whilst the increase in inequality in the UK slowed significantly in the 2000s, it grew more quickly among other OECD countries than it did in the UK during this period, and it grew most rapidly among the traditionally low-inequality Nordic countries (OECD, 2011). The Nordic countries' relatively more rapid increase in inequality over the past decade is the result of both increasing market income inequality and a reduction in the effectiveness of redistributive policies (OECD, 2011).

The level and trend of inequality is very similar in Scotland to that in rUK outside London. Whilst inequality in a broad sense has remained relatively unchanged since the late 1990s, the very highest $1-2 \%$ of earners have appropriated an increasing share of income. The richest $1 \%$ of Scotland's adult population earned $6.3 \%$ of total pre-tax incomes in 1997 , rising to $9.4 \%$ by 2009 . This trend towards an increasing appropriation of total income by the highest earners has occurred in all OECD countries (Sweden's richest 1\% have also increased their share of total income to 9\% for example), but has been particularly pronounced in English-speaking countries (Piketty and Saez, 2006). Explanations for the rise in top-pay include increased demand for executive managers; an increased 
ability of executives to set their own pay and extract rents at the expense of shareholders; a globalising market for 'superstar' CEOs and financial managers, and behavioural responses to reductions in marginal tax rates (Piketty and Saez, 2006, Bell and Van Reenen, 2013).

A number of commentators argue that the outlook for inequality is bleak. Ongoing technological change may further increase inequality via its effect on the skill premium (OECD, 2011, Beaudry, et al., 2013; Cowen, 2013). Furthermore, there is a view that the Coalition Government's policy of welfare reform and benefit cuts is likely to reverse the trend of static (or declining) net income inequality (Cribb, et al., 2012; Portes, 2011; Dickens, 2011). The Coalition Government aims to reduce the overall welfare bill whilst improving incentives for work, and its mid-term review highlighted that its welfare reforms so far introduced will save taxpayers $f 19$ billion per year by $2014 / 15$, (on total welfare spending of $£ 200$ billion). IFS analysis shows that the overall reforms introduced by the Coalition Government are regressive (Emmerson et al., 2013). This is pertinent for the independence debate because, to the extent that redistribution is a policy choice, support for Scottish independence draws heavily on the fact that the Scots demonstrate some evidence of greater preferences for social democratic policy configurations, which we discuss in the following section.

\section{Fiscal federalism and inequality}

This section draws on theories of fiscal federalism to consider the constraints that a Scottish Government might face in pursuing an independent redistributive policy, either as a wholly independent country, or with enhanced devolved fiscal powers within the existing UK.

Even in the case of a closed independent country (i.e. where there is no factor mobility between countries), a government is constrained in the level of redistribution that it can achieve by its internal budget constraint. In a simplified form ${ }^{4}$, tax revenue is raised from an aggregate tax rate, $t$, applied to aggregate per capita income, $Y$, and used to pay for public goods, $G$, at price $p_{G}$, and for redistribution in the form of a uniform payment, $B$. For given $G$, there is then a frontier relating $t$ and $B$. Higher taxes allow a larger $B$, but, since $Y$ falls with $t$, this trade-off becomes progressively less and less attractive, and there may be a maximum $B$ at tax rates less than 100 per cent. This illustrates what Mirlees et al. refer to as 'the inevitable trade-off between redistribution and work incentives'.

The three factors that determine the optimal tax rate in the above calculation are the price of public goods, the elasticity of taxable income with respect to the tax rate, and the relative preference for overall output against redistribution. Deaner \& Phillips (2013) do not find any evidence ${ }^{5}$ that the price of public goods is systematically different by country size in the EU, and so we cannot have any expectation that the price of public goods in an autonomous Scotland will be different, in either direction, from a centrally administered UK. It seems unlikely that taxable income elasticities differ in Scotland compared to rUK (Bargain et al. 2013 find little evidence of differences in labour supply elasticities across $17 \mathrm{EU}$ countries). It is possible that greater preference for redistribution in Scotland could lead to an autonomous Scotland choosing a higher level of redistribution than the

\footnotetext{
${ }^{4}$ We are indebted to an anonymous referee for providing this exposition.

${ }^{5}$ Section 5.1 'Spending by service area - how might it change?' on page 62 and 63
} 
UK. The government of an autonomous Scotland may be willing to accept some efficiency losses in return for an increased level of redistribution.

Where factors are mobile between countries, governments may face even greater constraints to the level of redistribution that they can attain. With factor mobility, theory predicts that there is likely to be downward pressure on tax rates, and an inefficiently low level of redistribution and public services. Between countries however, labour tends to be relatively immobile due to the existence of 'border effects' in migration (Helliwell, 1997). The evidence presented in the previous section whereby different independent countries are seen to achieve different levels of redistribution supports this contention that frictions on factor mobility between nation states are, in the long run, likely sufficient to ensure the sustainability of some level of differences in redistributive policies.

Within a nation state, the absence of border effects means that factor mobility tends to be relatively higher than it is between countries. The relatively high level of mobility of factors within countries explains why traditional theories of fiscal federalism argue that redistributive policy should be reserved at the federal level, rather than being decentralised to devolved levels of government. The traditional theory contends that efforts at redistribution at a sub-national level will be undermined by the mobility of workers, with the result being no redistribution but deadweight losses from inefficient locational decisions (Oates, 1999).

A number of empirical studies find evidence that factors do respond to tax changes within territories. Milligan and Smart (2013) for example show that the shifting of taxable income between provinces accounts for about two thirds of the total tax avoidance in response to unilateral provincial tax changes. Feld and Kirchgasser (2002) show that income tax-rate differences across Swiss Cantons influence firm location through the influence of firms' ability to attract skilled labour. There is also evidence that migration across countries may be induced by country specific tax reforms for high earners such as footballers (Landais et al 2013). On the whole however, migration between countries, as noted above, tends to be much lower than within countries; Gordon and Cullen (2012) hypothesise that limited labour mobility between countries of the EU may explain why the EU engages to only a limited extent in redistributive policy.

The ability of policy within a jurisdiction to have an effect upon inequality outcomes is thus closely related to the question of factor mobility. In the remainder of this section we focus on the ability of a decentralised jurisdiction within a national economy to influence the level of inequality, but the discussion applies also to the early years (which possibly extend to the working lifetimes of the current working population, or even beyond) of a newly independent state which will likely maintain a high level of mobility with respect to its former partners.

Theories of fiscal federalism make no allowance for history, and assume we are starting from a blank slate. The mobility of factors of production will be heavily influenced by the existing and historical institutions and the expectations of economic agents which will be largely determined by their experiences to-date. The UK has evolved as a unitary state, with virtually all fiscal levers reserved at Westminster, and with many shared institutions. Relative to international mobility, there is a high degree of factor mobility within the UK which will only change slowly, even if the constitution changes. However, factors are not perfectly mobile within a state, and the less mobile are factors of production, the more scope there is for policy differentiation, and so for fiscal decentralisation. For example, a number of studies, e.g. Blanchflower \& Oswald (2013) for the UK and Isebaert et al. 
(2011) for Belgium, provide evidence that high home ownership rates damage the labour market by impeding labour mobility. Whilst this is not evidence of frictions in the response of individuals to inter-regional tax differences, it is evidence of less than perfect mobility. Assuming that there is some substantial degree of factor immobility within nations, clearly not to the same extent as that between nations but still significant, then we can conclude that decentralisation of policy can lead to some real degree of policy autonomy, and that real effects can be observed.

Even where there is significant factor mobility, there may still be a case for decentralisation of some redistributive functions. Indeed, Oates (2005) notes that, despite what might be anticipated by the theories of fiscal federalism, "welfare reform is in the vanguard of US moves towards fiscal decentralisation", whilst Gordon and Cullen (2012) similarly point out that US States are heavily involved in redistributive policy-making, despite the negative horizontal externalities that this entails.

One potential explanation for this apparent paradox is that it reflects a response to differential local preferences. As noted by Hughes (1987): "the key allocative advantage of autonomous local governments must be found in their capacity to collect better information about local preferences and to respond to this information in making expenditure and taxation decisions". Oates (2005) states that the trade-off between the functions of the central and decentralised governments can be characterised as: "on the one hand, the inefficiencies under centralised provision of public services stemming from more uniform outputs that fail to reflect divergences in local tastes and conditions, versus, on the other hand, inefficiencies in local provision resulting from the failure to internalize inter-jurisdictional externalities".

This preference-based justification for devolution of redistributive policy levers interacts with labour mobility in exactly the opposite way from the financial sustainability of redistribution. With mobile populations and varied local policy implementations, individuals can relocate to those locations which provide the desired levels of public goods i.e. labour mobility should enhance the heterogeneity of preferences and so enhance the justification for decentralisation (Tiebout, 1956). If preferences are sufficiently heterogeneous, there may be a negative interdependence between jurisdictions in the tax rate and level of redistribution; in such a case, decentralisation leads to a more efficient provision of public services than if services are centralised and provided at uniform level (Tselios et al).

There does appear to be some evidence for preference heterogeneity between Scotland and the rest of the UK. As well as persistent differences in voting patterns, according to the British Social Attitudes Survey Scots are: more likely than English voters to think the gap between high and low incomes is too large (78\% v. $74 \%)$; are more likely to support government efforts at redistribution ( $43 \%$ v. $34 \%)$; are more likely to say that social benefits are not high enough (6.2\% v. $3.6 \%)$; and more likely to say that unemployment benefits are too low and cause hardship (22\% v. $18 \%)$. Perhaps we are in an intermediate world with sufficiently strong labour mobility for heterogeneous preferences, but sufficiently weak labour mobility to sustain policy differences without the need for fiscal transfers. Alternatively, perhaps there is strong labour mobility and hence heterogeneous preferences, but if these are met through differential policy, policy will not be fiscally sustainable because of the induced movement of labour. Another alternative is that there is a lack of labour mobility and preference heterogeneity arises for some other reasons, if this is the case then policy 
differentiation may be fiscally sustainable. In this paper we treat preferences as exogenous, and take the desire for policy differentiation (either via independence or further devolution) as given, and look at the fiscal sustainability of improving the income distribution, taking into account the impact that this may be estimated to have on the movement of labour.

Decentralisation itself also has an impact upon behavioural responses: if a particular level of redistribution is deemed optimal, calculated over the population of the whole national economy, then the very act of political decentralisation will decrease this optimal level of redistribution. Suppose a national economy under a single central government splits into two sub-national bodies in federation. Suppose further that these bodies each desire different levels of redistribution such that the overall level of redistribution in the aggregate economy is unchanged from the situation under the single, central government. The low redistribution region represents an option to relocate for the high earners in the high redistribution region, and the high redistribution region represents an option to relocate for the low earners in the low redistribution region. The elasticity of labour mobility to the degree of redistribution has increased because of the fact of decentralisation. Taking this into account will mean that the aggregate level of redistribution under decentralisation is lower than the aggregate level of redistribution under a single national government.

However, a mechanism can also be proposed for how independence or enhanced devolution could increase the aggregate level of redistribution across the UK. The political direction of the UK may be set by the political colour of the marginal seats at Westminster, which are much less for redistribution than the average of political opinion in Scotland. This focus may determine the position of political debate and the Overton Window ${ }^{6}$ of acceptable political change. If Scotland were to set its own redistribution policies, and be seen to do so in self-financed manner, then Scotland could act as a beacon of what can reasonably be achieved, changing the political weather in the rest of the UK. This is consistent with the idea in Oates (1999) of 'laboratory federalism' (i.e. learning through policy experimentation) across jurisdictions, which can promote policy innovation, and is proposed by Oates (2005) as a potential explanation for the increased engagement of US States in redistributive policy. Indeed, empirically Tselios et al. (2012) analyse within-region inequality in Western European regions, and find that "greater fiscal decentralisation is associated with lower interpersonal income inequality". Explanations may include the importance of devolved government revenue generation to make local governments more responsive to citizens, reduce corruption, and increase the incentives to provide market-enhancing public goods, consistent with ideas from the so-called second generation theory of fiscal federalism (Weingast, 2009).

Overall, theory suggests that the level of constraint faced by an independent Scottish Government in pursuing a given redistributive policy will depend on the degree of factor mobility to neighbouring jurisdictions, and the policy pursued in those jurisdictions. By becoming independent, the level of mobility between Scotland and rUK may reduce over time, as border effects emerge. In theory this reduces some of the constraints faced by the Scottish Government in pursuing independent policy. But it may also create an additional constraint - if independence for Scotland moves rUK politics in the direction of less redistribution (due to lower preferences for is redistribution there) - then that

\footnotetext{
${ }^{6}$ Wikipedia defines the Overton Window as 'the range of ideas that the public will accept. On this theory, an idea's political viability depends mainly on whether it falls within that window rather than on politicians' individual preferences. It is named for its originator, Joseph P. Overton.'
} 
may make pursuit of a more redistributive policy than that currently pursued by the UK Government even more difficult in Scotland.

\section{Scottish constitutional futures}

The Scottish Government relies on a block grant from the Westminster Government to finance the vast majority of its spending ${ }^{7}$. Devolved governments almost always face a 'vertical fiscal imbalance' - a mismatch between their spending and revenue raising powers - which arise because of the advantages of taxation at the state level and spending at a devolved level. However, the level of vertical fiscal imbalance faced by the Scottish Government is particularly high relative to that of devolved governments in most other OECD countries (Commission on Scottish Devolution, para 3.29). This is seen as a disadvantage because it reduces the accountability of the Scottish Government to its electorate. The argument was summarised by the Calman Commission thus: "Funding by block grant alone means that while the Scottish Parliament is completely accountable for the spending of its budget, it is not accountable for the total of that budget or how it is raised; it has no fiscal powers that can be used as policy instruments and it does not have a direct financial stake in the performance of the Scottish economy" (Commission on Scottish Devolution, 2009, para 3.87).

The desire to reduce the Scottish Government's high vertical fiscal imbalance has motivated much of the recent debate around alternative constitutional arrangements for Scotland. Thus whilst a yes vote at the Independence Referendum will clearly result in the Scottish Parliament taking responsibility for all tax and spend decisions, it is possible that a no vote will eventually be followed by further fiscal devolution to Scotland.

Indeed, following the recommendations of the Calman Commission (Commission on Scottish Devolution, 2009), which emphasised the need to improve the accountability of the Scottish Parliament by reducing its dependence on grant, the Scotland Act was enacted in 2012. This will see the Scottish Parliament take responsibility for setting a 'Scottish Rate of Income Tax' (SRIT), a flat rate tax set at the same rate for each (UK government-determined) income tax band, which will bring around $40 \%$ of the revenues from all income tax raised in Scotland under the control of the Scottish Parliament ${ }^{8}$. The Scotland Act is therefore consistent with the traditional theory of fiscal federalism, in that it effectively reserves redistribution at central government level. The income tax proposals in the Scotland Act will start to be implemented from 2016 onwards, but there is already significant debate around which further revenue streams (and spending responsibilities ${ }^{9}$ ) should be

\footnotetext{
${ }^{7}$ The Scottish Government has responsibility for council tax and business rates, equivalent to $£ 4$ billion revenue in 2011/12, compared to a total budget of $£ 33$ billion in the same year.

${ }^{8}$ From April 2016 the basic, higher and top rates of income tax levied on earned income by the UK Government in Scotland will be reduced by 10p. They will be replaced by a new Scottish Rate of Income Tax (SRIT) which will be set by the Scottish Government. The revenue collected from the SRIT will then form part of the Scottish budget. If the Scottish Government chooses to set the SRIT at 10p; the basic, higher and top rates of income tax in Scotland will remain at the same levels as in the rest of the UK.

9 Most major items of public expenditure are devolved to the Scottish Parliament (including health, education, local government, transport, housing, environment, and police and justice). The major items of public spending that remain reserved to the Westminster Government are welfare (i.e. benefits and state pensions) and defence.
} 
devolved in the event of a no vote at next September's referendum. Proponents of 'devo-more', 'devo-plus', and 'devo-max' have put forward proposals for varying degrees of further devolution. These are summarised stylistically in Table 1 , and can be summarised as follows:

- Devo-more: put forward by Alan Trench and IPPR (Trench, 2013), devo-more proposes the full devolution of income tax and assignment of 10 percentage points of VAT to the Scottish Parliament, together with a longer-term ambition to devolve alcohol and tobacco duties (assigned in the first instance), and potentially National Insurance contributions. Welfare spending remains reserved.

- Devo-plus: proposed by former Liberal Democrat MSP Jeremy Purvis and the Reform Scotland think-tank, the devo-plus proposals (Purvis, 2012) also include the outright devolution of income tax (although with responsibility for thresholds remaining with the UK government). But unlike devo-more, the devo-plus proposals include devolution of capital gains and inheritance tax, and devolution of aspects of corporation tax (thresholds and some special rates would be reserved). Conversely, VAT is not proposed for assignment, nor are alcohol or tobacco duties (although the desirability of devolving alcohol and tobacco duties in the longer run is recognised). Devo-Plus also differs from Devo-More in that it supports devolution of some aspects of social security spending (see Table 1).

- Devo-max: also known as full fiscal autonomy, devo-max proposes welfare spending to be devolved to the Scottish Parliament, and for the Scottish Parliament to take-on responsibility for all taxes levied in Scotland other than VAT. Devo-max is similar to the system of finance used by the Basque and Navarre Autonomous Communities of Spain (see Ruiz-Huerta and Castells, this issue).

Thus the Scottish constitutional debate is more wide-ranging than the simple yes-no question on the table at next year's referendum. Each of the three intermediate models of devolution is motivated by an ambition to reduce the level of vertical fiscal imbalance faced by the Scottish Government, although the proposals differ substantively in relation to which taxes are most suitable for devolution. These proposals for go beyond the recommendations of the traditional fiscal federalism literature, in that they allow for varying degrees of redistributive policy. As discussed in Section 3 , the effectiveness of these levers may depend on the degree of factor mobility. 
Table 1: Proposals for devolution of taxation and spending responsibilities under various models of government

\begin{tabular}{|c|c|c|}
\hline Model of government & Spending proposals & Taxation proposals \\
\hline $\begin{array}{l}\text { Status quo (Scotland Act } \\
\text { 2012) }\end{array}$ & - As current & $\begin{array}{l}\text { - Scottish Rate of Income Tax (SRIT): flat- } \\
\text { rate tax } \\
\text { - Some smaller taxes devolved entirely } \\
\text { (stamp-duty and landfill tax) }\end{array}$ \\
\hline Devo-more & - As current & $\begin{array}{l}\text { - Full devolution of income tax } \\
\text { - VAT revenues shared between Scottish } \\
\text { and Westminster governments } \\
\text { (Westminster retains control over rate) } \\
\text { - Devolution of capital gains tax on land } \\
\text { transactions } \\
\text { - Assignment of alcohol and tobacco } \\
\text { duties - to be devolved in long-run }\end{array}$ \\
\hline Devo-plus & $\begin{array}{l}\text { - Supports devolution of some aspects } \\
\text { of social security spending. } \\
\text { - In short-term: Attendance } \\
\text { Allowance, Winter Fuel Payments, } \\
\text { Carer's Allowance, and Jobcentre } \\
\text { Plus Social Provision, accounting for } \\
\text { f1 billion of Scotland's } f 20 \text { billion } \\
\text { social welfare bill. } \\
\text { - Longer-term to include a much } \\
\text { broader range of benefits spending } \\
\text { associated with labour markets, low } \\
\text { incomes, disability and housing }\end{array}$ & $\begin{array}{l}\text { - Devolution of income tax rates, but } \\
\text { thresholds reserved initially } \\
\text { - Devolution of inheritance tax and } \\
\text { capital gains tax } \\
\text { - Corporation tax rate devolved; some } \\
\text { thresholds and reliefs reserved } \\
\text { - Alcohol and tobacco duties devolved in } \\
\text { longer-term }\end{array}$ \\
\hline Devo-max & $\begin{array}{l}\text { Devolve welfare spending; only } \\
\text { defence and foreign affairs remain } \\
\text { reserved }\end{array}$ & $\begin{array}{l}\text { - All taxes other than VAT devolved to } \\
\text { Scottish Parliament }\end{array}$ \\
\hline Full independence & \multicolumn{2}{|c|}{$\begin{array}{l}\text { - All taxes and spending decisions are the responsibility of the Scottish } \\
\text { Government }\end{array}$} \\
\hline
\end{tabular}

\section{Approach}

\subsection{A household level model of the Scottish economy}

The analysis in this paper considers the effectiveness of different tax and benefit policy levers in addressing inequality. The results use a household level model of the Scottish economy. The model takes as its starting point the Family Resources Survey (FRS), a representative survey of over 4,000 households in Scotland. Surveyed households report information on household size and composition, tenure, and council tax band, as well as information for each individual in the household on age, employment status and working hours, income by source, benefit eligibility and receipt, and information on disability and caring responsibilities.

The model uses this information to calculate the liability of each household for income tax, national insurance ( $\mathrm{NI}$ ) and council tax, and the level of benefits and tax credits received. Furthermore, it incorporates data from the Family Expenditure Survey (FES) to estimate household expenditure shares on different categories of goods, and consequently the level of VAT and excise duties accruing from each household. As such, the model can be used to examine the effect of the existing fiscal 
system on the distribution of net household income, and, by aggregating over all households, it can be used to estimate aggregate government tax revenues and expenditure on tax credits and benefits.

Table A1 in Appendix A reconciles the model output on tax revenues and benefit expenditures with official data from relevant sources. The model performs well on tax revenues (though its estimate of VAT is low because household expenditure from wealth or investment income is not included and because some VAT is paid by businesses rather than households). In terms of benefits, the model performs relatively well for the State Pension, Child Benefit and Tax Credits (it overestimates Tax Credit somewhat as a result of under claiming, i.e. not all of those eligible to claim do so). The model tends to underestimate expenditure on out-of-work and disability benefits: this is a result of underreporting of these benefits in the FRS.

As well as reconciling the model in terms of aggregate government taxes and spending, it is also important, given the objective of this work, to reconcile the model with actual data in respect of the distribution of income across households. The model estimates the GINI coefficient of inequality (for net equivalised household income) at 29.4; this is reasonably close to the Scottish Government's estimate of 30.4 (and within the 95\% confidence interval, 29.1 - 31.7). Figure A1 in Annex A compares the model's estimate of household income by decile with that of the Households Below Average Income (HBAl) survey produced by the DWP. The model underestimates incomes of the highest decile (because, unlike HBAl, data on the highest earners is not supplemented by information from the Survey of Personal Incomes), and slightly overestimates incomes of households in deciles 5-9. On balance however, the model provides a good fit to the 'actual' income distribution in Scotland. More importantly, the model is capable of calculating the effect of specific fiscal changes (such as a change to a tax threshold or benefit rate) on both the distribution of net household incomes, and aggregate government revenues and expenditure.

\subsection{Incorporating behavioural responses}

In modelling the impact of fiscal changes on aggregate tax revenues and the income distribution, it is important to consider the possible effects of household behavioural responses to tax changes. Our model incorporates two types of household behavioural response: a migration response, and a labour-supply response. The remainder of this section describes the assumptions underlying the modelling of these behavioural responses. The magnitude of the behavioural response to changes in marginal and average effective tax rates is uncertain. We calibrate our behavioural responses using existing literature, and provide some sensitivity analysis in Annex B. The calibration is based on the assumption that the rest of the UK does not respond to Scottish policy autonomy. Therefore, in the base scenario there are no behavioural responses. As discussed in section 3, greater preferences for redistribution in Scotland relative to the UK, imply a lower preference for redistribution in rUK relative to UK and so the assumption that there are no behavioural responses in the base scenario may be question. Further, decentralisation itself may lower equilibrium levels of redistribution. However, for simplicity and tractability, we assume that rUK maintains UK policy and so there are no behavioural responses if Scotland too retains UK policy. We also use higher behavioural response estimates, as discussed below, for Scotland than for UK to allow the 'constant policy rUK' to act as an outside option for mobile Scottish households. 


\section{Migration response}

Fiscal policy changes may induce migration, particularly in the case of high income individuals: a low average tax rate may attract immigration, and a high average tax rate may induce emigration. We model this behaviour by varying the weight given to individuals in the sample as a function of the change in the effective average tax rate.

For the migration response, we assume a simple model in which potential market earnings for an individual do not differ across countries, and in which the fixed costs of migration are distributed independently of market earnings. Individuals choose to migrate if the net-of-total-tax benefits of moving (in either direction) outweigh the idiosyncratic fixed costs. Since possible benefits decline as we move down the market earnings distribution, this channel will only be of importance to those at the top of the earnings distribution. This simple model is calibrated against the model described in the Holtham Report (Independent Commission on Funding and Finance for Wales, 2010) that "following a one pence increase in the higher rate of income tax in Wales, ... [750] people chose to leave Wales". We assume that, grossing up to reflect the higher population, the same is true of Scotland. Calibrating to Wales is likely to be prudent for Scotland since Scotland is less integrated into the UK than Wales (as discussed in the Holtham Report, and also evidenced by e.g. Ratti et al. (2010)). In the sensitivity analysis in Annex B, we vary this Welsh estimate of 750 people from 500 people in the weak response sensitivity to 1000 people in the strong response sensitivity.

\section{Labour-supply response}

There are broadly two types of possible labour supply response to a fiscal policy change. One is a response on the 'intensive' margin: individuals could respond by varying their hours worked or their reported taxable income. The other is a response on the 'extensive' labour margin: individuals might choose to enter or exit the labour market completely in response to a fiscal policy change.

We do not include an extensive labour market response. We acknowledge that the lack of such an extensive margin response is a deficiency of the model, and that the decision to model the labour supply in this way is purely for reasons of practicality. To incorporate an extensive margin response would have required creating new households in the dataset with some given market income, as a function of work incentives. A detailed model of what these households and their market incomes would look like would need to have been constructed.

We model the labour-supply response on the intensive margin by varying market incomes as a function of the change in the effective marginal tax rate. The magnitude of the behavioural response to changes in marginal tax rates is highly uncertain. It is not clear even what direction the response may be to a rise in marginal taxes: a higher tax rate lowers the relative price of leisure and so might induce a switch into leisure and reduced work effort (substitution effect); but a high tax rate also reduces income and so encourages work effort since leisure is a normal good (income effect). We choose a behavioural response based on Institute for Fiscal Studies and HM Treasury estimates. 
Specifically, we adjust market earnings in response to changes in the marginal rate of tax by calibrating the elasticity of market earnings to marginal tax rates using the IFS's analysis of the introduction of the additional rate of income tax in the UK (Brewer, et al., 2012). This policy change was effectively a rise in the marginal tax rate faced by those earning over $f 150,000 p$.a. from $40 \%$ to $50 \%$. The IFS report that HMT estimated the income tax revenue raised from this new tax of $f 6.5 \mathrm{~B}$ without behavioural responses, and $\mathrm{f2}$.7B with behavioural responses i.e. a fall in direct revenues of $58 \%$. To allow for the fact that differential policy between Scotland and rUK will lead to higher elasticities than produced considering the UK as a homogeneous entity, we insist that our model, in quantifying the introduction of the additional rate of income tax, sees a fall in additional direct revenues from the new higher tax rate (i.e. income tax only) of $75 \%$, though we implement this after allowing for the migration response already calibrated.

We also consider that the elasticity will vary across the income distribution. Based on evidence from existing research, the Holtham Report assumes an elasticity of income with respect to the tax rate of -0.25 for basic rate taxpayers (who face a marginal effective tax rate, METR, estimated at $38.8 \%$ ), and around -0.50 for higher rate tax payers (who face an METR of $47.7 \%$ ). We assume that this relationship between the elasticity and the effective marginal tax rate holds, but that it varies over different market income deciles. If we were to assume a linear relationship then we would see that the elasticity becomes positive in the lower middle part of the market income distribution (where the effective marginal tax rate is lowest), in other words we would see that individuals respond to tax increases by working more. This may be true - if the income effect exceeds the substitution effect - but it likely does not hold as strongly as such a linear relationship suggests. A less aggressive assumption is to assume that this elasticity cannot change sign and instead is quadratic with a turning point at zero at the lowest effective marginal tax rate in the base policy.

By making the elasticity a function of the marginal tax rate, and by noting that the lowest income deciles face very high marginal taxes, we partially address the problem of work incentives in the model: reducing the marginal tax rates faced by these groups will see their market earnings rise. However, we only change market income by some percentage and so, if market income is initially zero, then it will still be zero after the behavioural response, and there is no adjustment along the extensive margin in the model.

By adjusting along the intensive margin, with large percentage adjustments for those who face high marginal tax rates, the model likely does a good job of modelling the behavioural response of high earners who adjust work hours or hide taxable earnings in response to policy changes. The model does a less good job with respect to the response of second earners in a household who enter or exit the labour market as a function of policy changes, but at least the sign will be right. Given that the exercise in this paper is to reduce inequality, policies that improve work incentives such that those currently outwith the labour force select into work will be evaluated conservatively, whilst policies that improve means tested benefits and worsen work incentives, such that marginal workers may choose to exit the labour force, will be evaluated aggressively.

\subsection{Summary}

In summary, the strength of the model is that it enables us to model the effect of detailed policy changes (including combinations of benefit and tax changes) on the income distribution, and on the 
whole of government revenues, considering not only the effect of 'direct' revenues from an income tax or benefit change, but also considering the effects on indirect tax revenues (VAT, alcohol and tobacco duties, etc.).

The model incorporates two types of behavioural response: a household migration response, and a labour-supply response on the intensive margin. The model does not incorporate labour-supply decisions on the extensive margin (i.e. the decision as to whether to work or not) which will clearly also be affected by fiscal policy change. Furthermore, the model does not contain a firm sector, and thus firm behaviour is implicitly assumed not to change in response to changes in fiscal policy. Moreover, the analysis in this paper is concerned with modelling changes in labour income, and does not consider how policy might influence savings and capital income.

The assumptions underpinning the migration and labour-supply responses are summarised in Table 2. Clearly there are significant uncertainties underlying the estimation of these parameters, and we provide some sensitivity analysis in Annex B. Despite these uncertainties, the modelling of the possible behavioural responses provides useful insights into the magnitude of constraints that an independent Scotland might face in exercising fiscal policy to achieve particular policy goals, as we describe in the following section.

Table 2: Summary of assumptions underlying behavioural response

\begin{tabular}{lcc}
\hline & Migration response & Intensive labour-market response \\
\hline Core assumption & $\begin{array}{c}750 * 5.3 / 3.1=1,282 \text { people migrate in } \\
\text { response to } 1 \mathrm{p} \text { rise in higher (and } \\
\text { additional) rate tax }\end{array}$ & $\begin{array}{c}\text { Additional direct revenues from } \\
\text { introduction of Additional Rate } \\
\text { reduced by } 75 \% \text { due to combination } \\
\text { of migration and intensive labour } \\
\text { market response }\end{array}$ \\
\hline $\begin{array}{c}\text { (5.3 and 3.1 represent the population, } \\
\text { in millions, of Scotland and Wales } \\
\text { respectively) }\end{array}$ & $\begin{array}{c}\text { HM Treasury, cited in Brewer et al. } \\
2012\end{array}$ \\
\hline
\end{tabular}

* Independent Commission on Funding and Finance in Wales

\section{Results}

Table 3 considers the effect of a number of specific policy levers on inequality and government revenues in Scotland. Inequality is measured using the GINI coefficient; the income variable is net (after taxes and benefits) equivalised household income after housing costs. Figure 4 plots the effect of each policy on average household income for each decile of the income distribution.

Of the policy levers modelled in Table 3, the two council tax levers are already within the control of the Scottish Government; the Scottish Rate of Income Tax (SRIT) will come under the control of the Scottish Government in 2016; the other income tax levers have been proposed for devolution to the Scottish Parliament under both Devo-More and Devo-Plus constitutions; whilst the benefit levers would only come under the autonomy of the Scottish Government under Devo-Max or full independence.

The first four columns consider the impacts in the absence of behavioural effects, while the second five columns include behavioural effects, which are modelled as described in Section 5 and include 
both labour market and migration effects. Consider as an example the effect of a $1 \mathrm{p}$ increase in the basic rate. Without behavioural effects this would reduce the GINI by $0.13 \%$ and raise an additional $\mathrm{f395m}$ in income tax receipts. However, the consequential fall in incomes would lead to a fall in household spending and consequent reduction in revenues from VAT and excise duties, and thus the total impact on government finances is to raise net revenue by $£ 324 \mathrm{~m}$. With behavioural effects, the modelled increase in tax revenues is lower $(\mathrm{f} 343 \mathrm{~m})$, as taxpayers respond to the increase in tax rates by reducing their market income (either by working less or re-classifying elements of income), and in some cases by out-migrating. For the same reasons however, the reduction in inequality is greater than under the no behavioural effects scenario (i.e. the inclusion of behavioural effects means that we now capture the impact on inequality of reduced market incomes and reduced numbers of high earners, both in response to the tax increase).

The final column of Table 3 shows the largest percentage change in household incomes resulting from the policy change. This statistic informs assessment of the likely political acceptability of each policy - a policy which results in relatively small average income changes but large changes to individual households will likely be less politically feasible than a policy which produces smaller effects on individual households.

Looking through the various policy levers we can make the following observations.

- Adding $1 p$ to the higher rate has relatively inconsequential revenue implications (raising virtually no additional revenue once behavioural effects and reductions in indirect tax revenues are considered), and a relatively small impact overall on the GINI. However, precisely because the policy has such a small revenue effect, the reduction in GINI for a f1m increase in Government revenues is substantial.

- Adding $1 p$ to the SRIT would, once behavioural effects are considered, reduce the GINI by $0.24 \%$ while raising net government revenues by $£ 232 \mathrm{~m}$. Expressed per $£ 1 \mathrm{~m}$ of revenue raised however suggests that the SRIT is not a particularly efficient policy for reducing inequality.

- Reducing the additional rate threshold to $f 100,000$ (from $f 150,000$ ) would increase the number of additional rate taxpaying households from 11,000 to 25,000 . This policy reduces the GINI by $0.12 \%$, although total government revenues actually fall, once the effects of behavioural responses and the impacts on indirect revenues are taken into consideration.

- Increasing rates of Jobseeker's Allowance (JSA) and Income Support (IS) by $10 \%$ would cost the government some $f 73 \mathrm{~m}$ in increased benefit payments, although some of this would effectively be recouped through higher household spending feeding through to increased indirect tax revenues. Changing rates of JSA/IS is a relatively efficient way of reducing the GINI (in terms of the effect per $f 1 \mathrm{~m}$ revenue) given that the increased spending is concentrated at the lower end of the income distribution (Figure 4). However, we can see that there is relatively little difference between the behavioural and no behavioural simulations: this is because changes in the extensive labour supply are not modelled, and therefore the quantification of the impact of this policy must be viewed as an optimistic estimate. 
- The Council Tax revaluation specified here ${ }^{10}$ is virtually revenue neutral, raising an additional $\mathrm{f} 8 \mathrm{~m}$ in council tax revenues (relative to $\mathrm{f} 2 \mathrm{~b}$ total revenue from this source). This policy can achieve a high impact on inequality with minimal impact on overall government finances. However it can have large impacts at an individual level - there are a small number of households with low income but exposure to the top bands of council tax who are hit hard by this policy: compare the $5 \%$ loss in net household income for some households to the direct revenue raised of only $£ 8 m$.

- The council tax rise scenario is unusual in that a tax increase actually increases the GINI. This result occurs because a rise in council tax disproportionately affects lower and middleincome households: higher income households' council tax liability is smaller as a proportion of their income than lower income households; so a flat percentage rise in the rate of council tax is more burdensome on the lower half of the income distribution.

- The change to working tax credit modelled here is a $10 \%$ increase in the basic and 30 -hour elements of working tax credit rates. This policy change achieves a relatively moderate reduction in the GINI, as its impact is spread fairly evenly across the entire lower half of the income distribution. The cost of this policy is such that its marginal impact on the GINI is relatively modest. The relatively inefficient nature of this policy in terms of reducing inequality may result from the fact that it supplements the incomes of those in work rather than those out of work, and we do not model its impact on increasing the extensive labour supply.

There is clearly significant uncertainty around the level of the behavioural response. Table B1 in Annex B provides some sensitivity analysis, where we examine the extent to which the estimates of government revenues and the GINI measure of inequality vary under a weaker and a stronger level of behavioural response. Table B1 also provides further information on the magnitude of the migration response induced by each policy, by reporting the change in the number of households under each scenario.

Table B1 demonstrates that uncertainty around the strength of the behavioural response to fiscal policy changes can have non-negligible impacts on the magnitude, and sometimes even the direction of the effect on government revenues. For example, under the assumption of a weak behavioural response, the effect of adding $1 p$ to the higher rate of income tax is to increase government revenues by $f 17 \mathrm{~m}$, whereas the assumption of a stronger response results in a fall in total government revenues of $110 \mathrm{~m}$ (the number of out-migrating households is 2,600 and 5,400 in each case). However, the uncertainty around the magnitude of the behavioural response does not materially alter the relative ranking of the policies in terms of their effectiveness in reducing the GINI, and nor does it materially alter the conclusion that the policy levers examined here have a relatively small effect on reducing overall inequality in Scotland.

\footnotetext{
${ }^{10}$ The council tax revaluation scenario is based on reducing the lower council tax band rates and increasing the higher council tax band rates as follows. Band A: 0.67 -> 0.64; Band B: $0.79 \rightarrow 0.77$; Band C: 0.89 -> 0.88; Band D maintained = 1.0; Band E: 1.22 -> 1.25; Band F: 1.44 -> 1.50; Band G: 1.67 -> 1.75; Band H: 2.0 -> 2.1
} 
Table 3: Effect of various policy levers on inequality and government revenue

\begin{tabular}{|c|c|c|c|c|c|c|c|c|c|}
\hline & \multicolumn{4}{|c|}{ No behavioural effect } & \multicolumn{5}{|c|}{ Behavioural effect } \\
\hline & $\begin{array}{l}\text { Change } \\
\text { GINI }\end{array}$ & $\begin{array}{l}\text { Direct gvt } \\
\text { revenue } \\
\text { implication }\end{array}$ & $\begin{array}{l}\text { Total gvt } \\
\text { revenue } \\
\text { implication }\end{array}$ & $\begin{array}{l}\text { GINI effect } \\
\text { per } £ 1 \mathrm{~m} \\
\text { revenue } \\
\text { increase }\end{array}$ & $\begin{array}{c}\text { Change } \\
\text { GINI }\end{array}$ & $\begin{array}{l}\text { Direct gvt } \\
\text { revenue } \\
\text { implication }\end{array}$ & $\begin{array}{l}\text { Total gvt } \\
\text { revenue } \\
\text { implication }\end{array}$ & $\begin{array}{l}\text { GINI effect } \\
\text { per } f 1 m \\
\text { revenue } \\
\text { increase }\end{array}$ & $\begin{array}{l}\text { Largest } \mathrm{HH} \\
\text { income } \\
\text { change }\end{array}$ \\
\hline $1 p$ on basic rate & $-0.134 \%$ & 395 & 320 & $-0.0004 \%$ & $-0.149 \%$ & 343 & 208 & $-0.0007 \%$ & $-4 \%$ \\
\hline $1 p$ on higher rate & $-0.048 \%$ & 54 & 43 & $-0.0011 \%$ & $-0.068 \%$ & 32 & 2 & $-0.0276 \%$ & $-1 \%$ \\
\hline $\begin{array}{l}\text { 1p on SRIT (basic, } \\
\text { higher, additional) } \\
\text { Additional rate }\end{array}$ & $-0.190 \%$ & 458 & 370 & $-0.0005 \%$ & $-0.239 \%$ & 370 & 197 & $-0.0012 \%$ & $-4 \%$ \\
\hline $\begin{array}{l}\text { threshold reduced to } \\
£ 100,000\end{array}$ & $-0.074 \%$ & 83 & 65 & $-0.0011 \%$ & $-0.122 \%$ & 26 & -28 & $0.0044 \%$ & $-5 \%$ \\
\hline $\begin{array}{l}\text { Increase rates of IS/ } \\
\text { JSA by } 10 \%\end{array}$ & $-0.151 \%$ & -73 & -60 & $0.0025 \%$ & $-0.150 \%$ & -74 & -60 & $0.0025 \%$ & $10 \%$ \\
\hline Council tax revaluation & $-0.017 \%$ & 8 & 6 & $-0.0029 \%$ & $-0.017 \%$ & 8 & 6 & $-0.0029 \%$ & $-5 \%$ \\
\hline Council tax rise of $10 \%$ & $0.024 \%$ & 188 & 153 & $0.0002 \%$ & $0.029 \%$ & 185 & 124 & $0.0002 \%$ & $-13 \%$ \\
\hline $\begin{array}{l}\text { Increase basic and } 30- \\
\text { hour elements of WTC } \\
10 \%\end{array}$ & $-0.068 \%$ & -84 & -63 & $0.0011 \%$ & $-0.069 \%$ & -84 & -60 & $0.0012 \%$ & $9 \%$ \\
\hline
\end{tabular}


Figure 4: Effect of various policy levers on average household incomes by decile
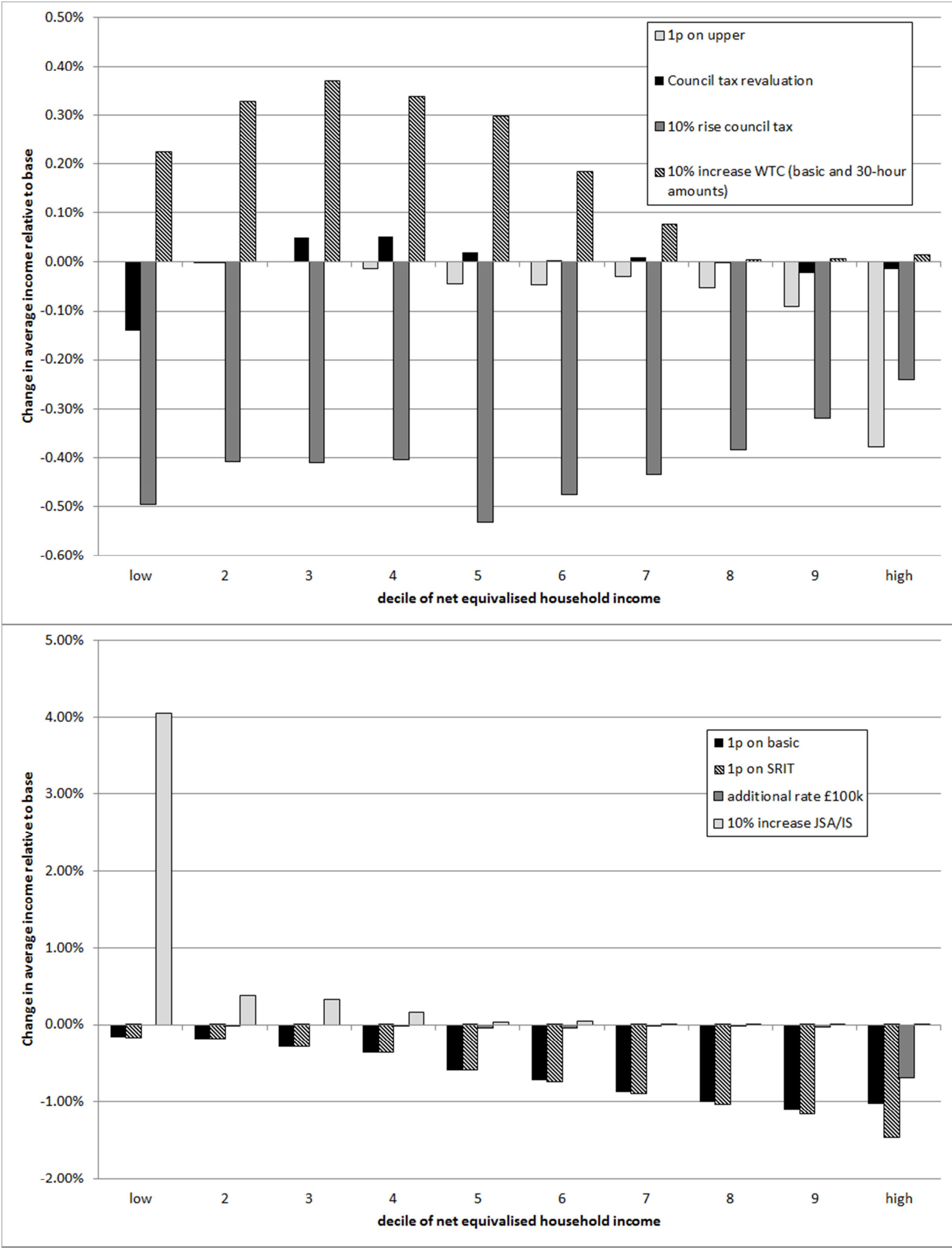
The analysis in this paper has focussed on fiscal levers that the Scottish Government might exercise. An independent Scotland would also have other levers at its disposable. One possibility is to raise the minimum wage, or to establish a legal living wage. There is policy impetus for both policies: the Social Mobility Commission (2013) supported the idea of a higher national minimum wage; and the Scottish Government has expressed its commitment to the notion of a living wage.

Data from the Labour Force Survey (LFS) in 2012 suggests that 23\% of Scotland's labour force earned less than a living wage of $£ 7.20$ per hour (comparable figures for $G B$ as a whole range from $21 \%$ (Whittaker and Hurrell, 2013) to $27 \%$ (Riley, 2013)). A rough indication of the potential effect of introducing a living wage, both on the public finances and on income inequality, can be derived. For each worker earning less than the living wage, we raise their earnings to $f 7.20$ per hour and assume that there is no induced change in employment. Under these assumptions, the introduction of a living wage would reduce the GINI coefficient by around $0.36 \%$. The living wage reduces upper-tail inequality whilst slightly increasing lower tail inequality because it boosts the incomes of those in the middle of the income distribution (Figure 5). The direct costs to the public sector through higher wage bills are small. Only $9 \%$ of public sector employees in Scotland are paid less than a living wage, and the costs of increasing these workers' pay is around $197 \mathrm{~m}$. The increased earnings of all workers now paid the living wage increases tax revenues by over $f 550 \mathrm{~m}$. However, around $28 \%$ of private sector employees are paid less than the living wage, and the direct costs to employers of filling this gap (excluding employers $\mathrm{NI}$ and other on-costs) could be around $f 1.2$ billion. The extent to which employers would react by reducing employment is an open question (Riley, 2013, Butcher, 2012).

Figure 5: Effects of introducing a living wage on household incomes, by income decile

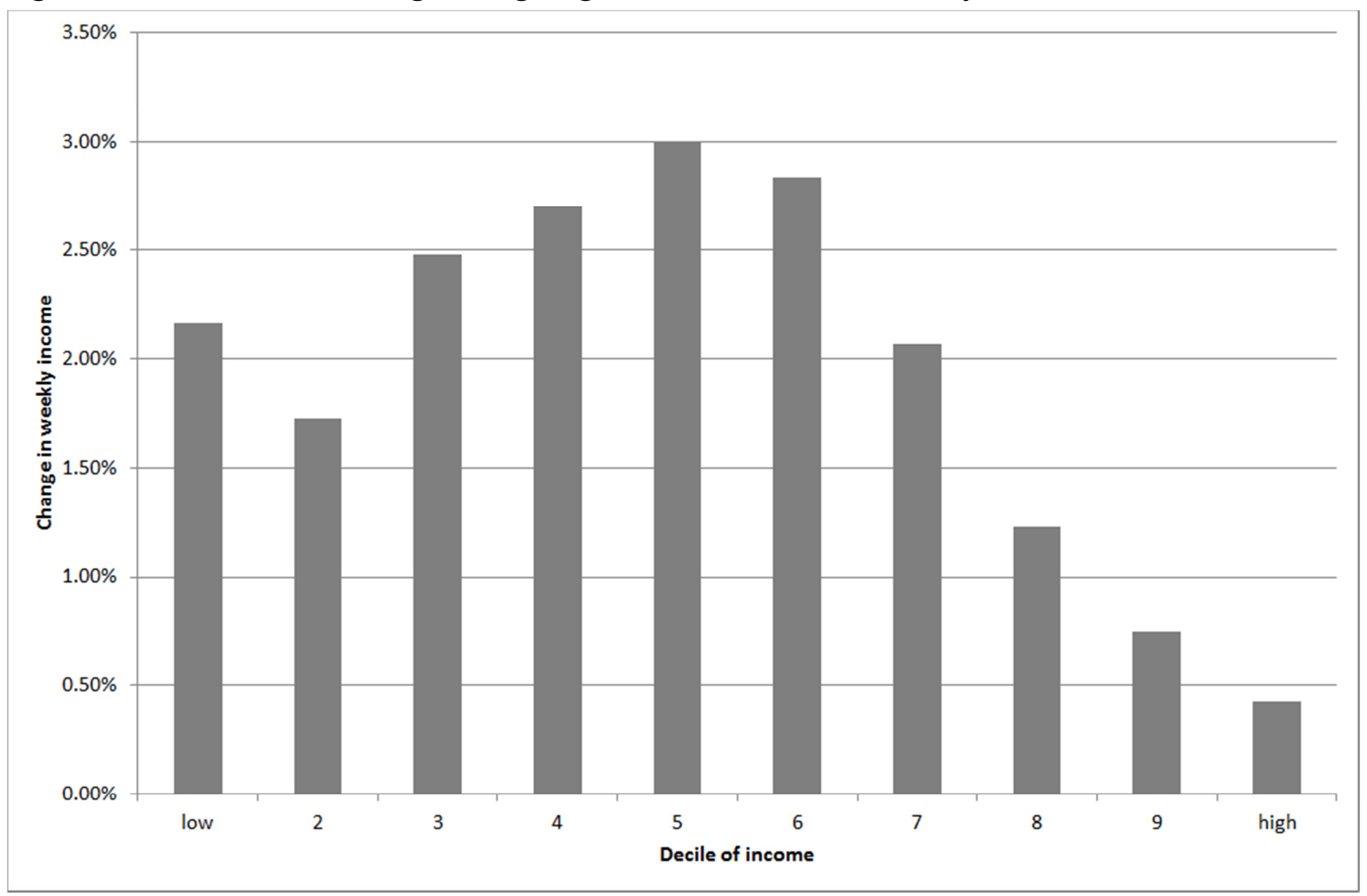




\section{Conclusions}

The Scottish Government has set out its ambitions to achieve a more equal distribution of income, and argues that these ambitions will only be achievable under full independence, and the complete autonomy to determine fiscal policy that this entails.

To achieve an equivalent level of net income inequality as in countries such as Denmark or Norway requires a fall in Scotland's GINI of around 5 percentage points. None of the relatively small changes to existing policies quantified in this analysis would achieve this level of inequality reduction. Indeed, the level of redistribution in the UK is not low in an OECD context, and even adoption of a 'Nordic' style redistributive policy is unlikely to enable Scotland to close its inequality gap with the Nordics, given Scotland's higher level of market-income inequality. Major policy changes however may induce large behavioural responses which could have the effect of undermining the fiscal impact of, for example, tax rises. Given the relatively high levels of market income inequality in the UK, achieving such substantial falls in the GINI through fiscal policy levers alone could be very challenging. Reducing market income inequality will be as important in this respect as the redistributive role of fiscal policy. Indeed, the 'Common Weal' project places much emphasis on the role that pre-distributive measures might play in the policy of an independent Scotland (Danson and Trebeck, 2013).

The fiscal policy levers which the Scottish Government already (or will soon) have access to are relatively blunt tools with which to address inequality given that they are not particularly sensitive to specific parts of the income distribution. We estimate that a penny on the Scottish Rate of Income Tax could reduce the GINI by around 0.2 percentage points, while changes in council tax seem unlikely to have a major impact on inequality (unless there was scope for a major revaluation of council tax bands).

Further devolution of income tax (at least to include the ability to vary rates differentially, but potentially also to vary thresholds as well), as proposed by the proponents of Devo-More and DevoPlus, would provide the Scottish Government an opportunity to more effectively use fiscal policy to influence the income distribution. But full control over low income and out of work welfare benefits would provide other important levers with which to influence inequality. This is because these levers can be used to target very specific segments of the population, in particular the segment of low earners who face large disincentive effects due to the very high marginal effective tax rates as benefits are withdrawn.

All governments face constraints on the extent to which they want to implement redistributive policy. The extent to which the government of a small open country or semi-autonomous region can achieve a different level of inequality from the wider economy of which it is part, is further constrained by labour mobility. Labour mobility is high within countries - even if they are decentralised - and it would likely also be high in the early years of an independent state. The analysis conducted in this paper incorporates this theory, and the results presented show that it is difficult for a small open economy to implement substantially different redistributive policy from that of its close partners. The effectiveness of policy in influencing inequality is of course subject to great uncertainty, but it is clear that, even with full autonomy for tax and benefit policy, the Scottish Government may need to look beyond fiscal policy and redistribution to achieve the substantial reductions in inequality that it desires. 


\section{Annex A: Reconciling the model}

Table A1: Reconciling the model, aggregate tax and spend

\begin{tabular}{|c|c|c|c|}
\hline & Data $(£ \mathrm{~m})$ & Model (£m) & Difference \\
\hline Income Tax & 10,668 & 10,499 & $98 \%$ \\
\hline $\mathrm{NI}$ & 7,978 & 8,104 & $102 \%$ \\
\hline VAT & 8,343 & 6,563 & $79 \%$ \\
\hline Excise Duties & 4,512 & 4,661 & $103 \%$ \\
\hline Council Tax & 1,968 & 1,927 & $98 \%$ \\
\hline Modelled Revenues (G) & 33,469 & 31,754 & $95 \%$ \\
\hline Out of Model & 18,861 & & $36 \%$ \\
\hline State Pension & 5,965 & 5,924 & $99 \%$ \\
\hline Child Benefit & 941 & 918 & $98 \%$ \\
\hline Low Pay Benefits: Tax Credits & 2,177 & 2,304 & $106 \%$ \\
\hline Low/Zero Inc Benefits: JSA, IS \& HB & 2,840 & 1,872 & $66 \%$ \\
\hline Disability Benefits: DLA, IB, ESA, SDA & 2,431 & 1,896 & $78 \%$ \\
\hline Modelled Expenditure (T) & 14,354 & 12,914 & $90 \%$ \\
\hline Out of Model & 49,676 & & $78 \%$ \\
\hline G-T modelled & $-19,115$ & $-18,840$ & $99 \%$ \\
\hline
\end{tabular}

Source: HMRC Tax Credit Statistics, Scottish Government GERS publication, DWP Benefit expenditure data

Figure A1: Reconciling the model, net income distribution

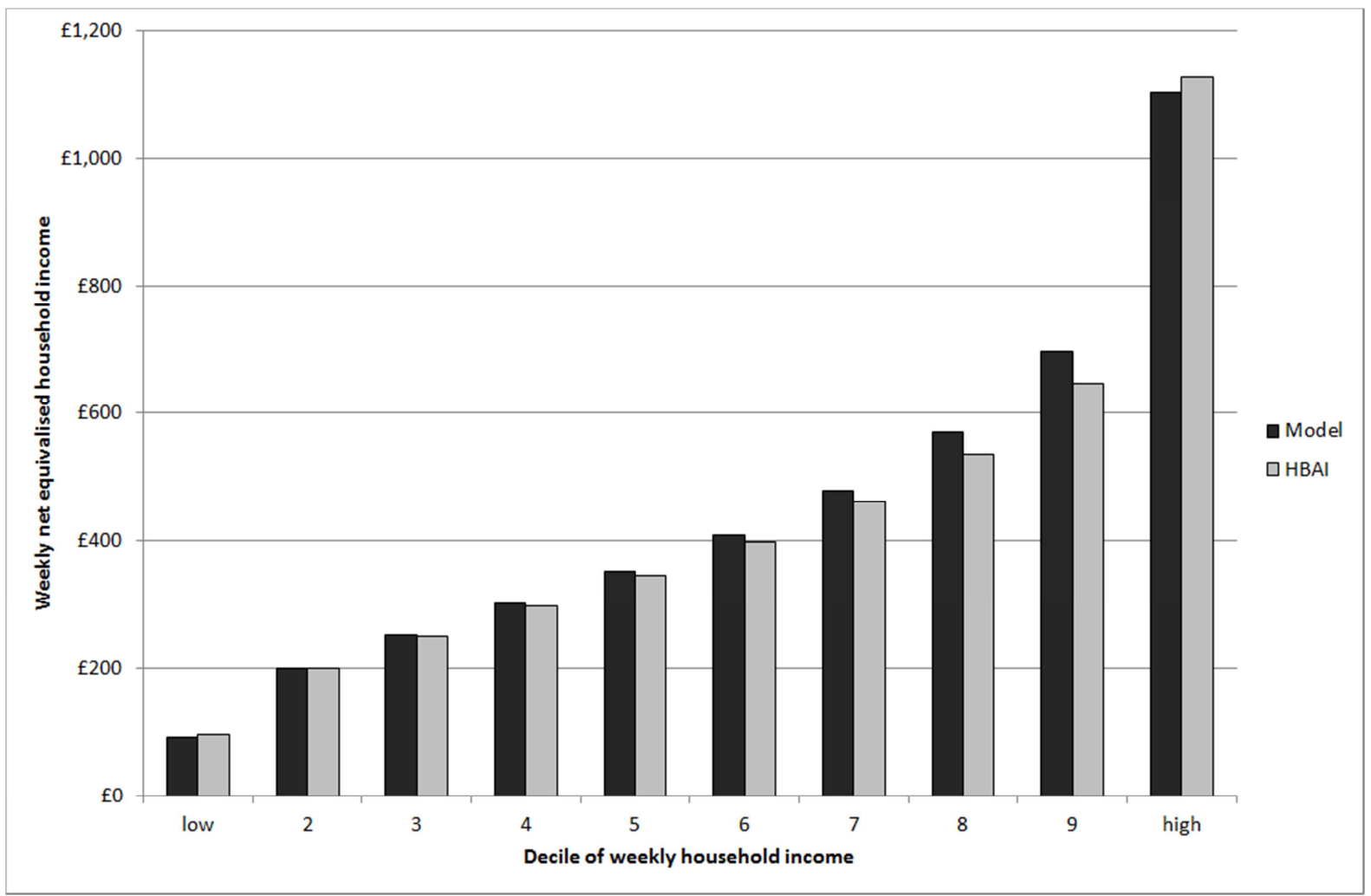




\section{Annex B: Behavioural Response Sensitivity Analysis}

In this Annex, we assess the sensitivities of our results to changes in the behavioural assumptions used. In the "central" scenario reported in the main body of the paper, 750 people migrated from Wales following a $1 p$ rise, to $41 p$, in Welsh higher and additional rate income tax, from 40p (this in conjunction with no tax change in the rest of the UK). We assumed that equivalently from Scotland, 750*5.3/3.1 = 1282 people migrate. Also in the central scenario, once this migration response was incorporated, we then required that behavioural responses to the introduction of the Additional Rate of income tax at 50p reduced the direct revenues from this tax by $75 \%$. This produced a required elasticity of gross earnings to marginal tax rates for the top decile of -0.215 (with quadratic dependence of this elasticity upon effective marginal tax rate, such that the slope of the elasticity curve against marginal tax rate was -0.5 for the marginal tax rates pertaining to the top decile).

In the "weak" response scenario, we suppose that Scotland sees migration of 500*5.3/3.0 = 855 following a rise in higher and additional rate tax from 40p to $41 p$, and we suppose that the elasticity of gross earnings to marginal tax rates for the top decile is $3 / 4 *-0.215=-0.161$. The "strong" response scenario has Scottish migration of $1000 * 5.3 / 3.1=1710$ people following a $1 \mathrm{p}$ rise in higher and additional rate tax, and an elasticity of gross earnings to marginal tax rates for the top decile of $5 / 4 *-0.215=-0.268$.

Table B1 differs from Table 2 slightly in that, rather than reporting the largest household income change under each policy (which remains approximately the same under the different behavioural response scenarios), we report the change in the number of people in Scotland induced by the policy. To give a sense of significance, the population of Scotland is 5.3 million people, so a migration of 5,847 people, as occurs under the weak behavioural response scenario to a $1 \mathrm{p}$ rise in the basic rate, is equivalent to $0.1 \%$ of the Scottish population.

Table B1 shows how the estimates of government revenue and inequality change under the weak and strong behavioural responses. There is significant uncertainty around the likely magnitude of the behavioural response, and Table B1 demonstrates that this uncertainty can have non-negligible impacts on the magnitude, and sometimes even the direction of the response. For example, under the assumption of a weak behavioural response, the effect of adding $1 p$ to the higher rate of income tax is to increase government revenues by $f 17 \mathrm{~m}$, whereas the assumption of a stronger response results in a fall in total government revenues of $f 10 m$. 
Table B1: Effect of various policy levers on inequality and government revenue

\begin{tabular}{|c|c|c|c|c|c|c|c|c|c|c|}
\hline & \multicolumn{5}{|c|}{ Weak response } & \multicolumn{5}{|c|}{ Strong response } \\
\hline & $\Delta \mathrm{GINI}$ & $\begin{array}{l}\Delta \text { direct gvt } \\
\text { revenue }\end{array}$ & $\begin{array}{l}\Delta \text { total gvt } \\
\text { revenue }\end{array}$ & $\begin{array}{l}\text { GINI effect } \\
\text { per } £ 1 \mathrm{~m} \\
\text { revenue } \\
\text { increase }\end{array}$ & $\begin{array}{c}\Delta \text { no. } \\
\text { people }\end{array}$ & $\Delta \mathrm{GINI}$ & $\begin{array}{l}\Delta \text { direct gvt } \\
\text { revenue }\end{array}$ & $\begin{array}{c}\Delta \text { total gvt } \\
\text { revenue }\end{array}$ & $\begin{array}{l}\text { GINI effect } \\
\text { per } £ 1 \mathrm{~m} \\
\text { revenue } \\
\text { increase }\end{array}$ & $\begin{array}{c}\Delta \text { no. } \\
\text { people }\end{array}$ \\
\hline $1 p$ on basic rate & $-0.146 \%$ & 359 & 243 & $-0.0006 \%$ & -5847 & $-0.153 \%$ & 327 & 172 & $-0.0009 \%$ & -12060 \\
\hline $1 p$ on higher rate & $-0.062 \%$ & 39 & 17 & $-0.0036 \%$ & -595 & $-0.074 \%$ & 25 & -10 & $0.0073 \%$ & -1388 \\
\hline $\begin{array}{l}\text { 1p on SRIT (basic, } \\
\text { higher, additional) }\end{array}$ & $-0.225 \%$ & 398 & 253 & $-0.0009 \%$ & -6669 & $-0.252 \%$ & 343 & 144 & $-0.0018 \%$ & -13762 \\
\hline $\begin{array}{l}\text { Additional rate } \\
\text { threshold reduced to } \\
f 100,000\end{array}$ & $-0.107 \%$ & 44 & 2 & $-0.0558 \%$ & -1063 & $-0.137 \%$ & 9 & -57 & $0.0024 \%$ & -2103 \\
\hline $\begin{array}{l}\text { Increase rates of IS/ } \\
\text { JSA by } 10 \%\end{array}$ & $-0.150 \%$ & -73 & -60 & $0.0025 \%$ & 7 & $-0.150 \%$ & -74 & -60 & $0.0025 \%$ & 87 \\
\hline Council tax revaluation & $-0.017 \%$ & 8 & 6 & $-0.0029 \%$ & 0 & $-0.018 \%$ & 8 & 5 & $-0.0036 \%$ & -31 \\
\hline Council tax rise of $10 \%$ & $0.028 \%$ & 186 & 134 & $0.0002 \%$ & -1664 & $0.031 \%$ & 184 & 114 & $0.0003 \%$ & -6787 \\
\hline $\begin{array}{l}\text { Increase basic and } 30- \\
\text { hour elements of WTC } \\
10 \%\end{array}$ & $-0.068 \%$ & -84 & -61 & $0.0011 \%$ & 45 & $-0.070 \%$ & -84 & -58 & $0.0012 \%$ & 869 \\
\hline
\end{tabular}




\section{References}

Amior, M., Crawford, R. and Tetlow, G. (2013) Fiscal sustainability of an independent Scotland. Institute for Fiscal Studies, London.

Bargain, O., Dolls, M., Neumann, D., Peichl, A., Siegloch, S. (2013) Comparing inequality aversion across countries when labour supply responses differ. International Tax and Public Finance, April 2013.

Beaudry P., Green D. A. and Sand B. M. (2013), The great reversal in the demand for skill and cognitive tasks. NBER Working Papers 18901.

Bell B. and Van Reenen J. (2013) Extreme wage inequality: pay at the very top. American economic review, 103 (3). 153-157

Bell D. and Eiser D. (2013) Inequality in Scotland: trends, drivers, and implications for the independence debate. Working paper, University of Stirling. http://esrcscotecon.files.wordpress.com/2013/11/inequality-paper-15-nov-final.pdf

Blanchflower D. and Oswald A. (2013) Does high home ownership impair the labour market, Working Paper., University of Warwick.

Brewer, M., Browne, J. and Johnson, P. (2012) The 50p income tax rate: what is known and what will be known? Institute for Fiscal Studies, London.

Butcher T. (2012) Still evidence-based? The role of policy evaluation in recession and beyond: the case of the National Minimum Wage, National Institute Economic Review 219, R26-40.

Commission on Scottish Devolution. (2009) Serving Scotland Better: Scotland and the United Kingdom in the 21st Century: Final Report, June 2009. Commission on Scottish Devolution, Edinburgh.

Cowen, T. (2013) Average is over: powering America beyond the age of the great stagnation. Dutton Books, New York.

Cribb, J., Joyce, R. and Phillips, D. (2012) Living standards, poverty and inequality in the UK: 2012. Institute for Fiscal Studies, London.

Danson, M. and Trebeck, K. (2013) No More Excuses: How a Common Weal approach can end poverty in Scotland. Jimmy Reid Foundation, Biggar.

Deaner, B. and Phillips, D. (2013) Government spending on public services in Scotland: current patterns and future issues. IFS Briefing Note BN140

Dickens R. (2011) Child Poverty in Britain: Past Lessons and Future Prospects, National Institute Economic Review 218, R7-R19.

Emmerson, C., Johnson, P. and Miller, H. (2013) IFS Green Budget 2013. Institute for Fiscal Studies, London. 
Feld L. P. and Kirchgässner G. (2003) The impact of corporate and personal income taxes on the location of firms and on employment: some panel evidence for the Swiss cantons, Journal of Public Economics 87, 129-55.

Gordon R. H. and Cullen J. B. (2011) Income redistribution in a Federal system of governments, Journal of Public Economics 96, 1100-1109.

Helliwell J. F. (1997) National borders, trade and migration, Pacific Economic Review 2, 165-85.

Hughes G. A. (1987) Fiscal federalism in the UK, Oxford Review of Economic Policy 3, 1-23.

Independent Commission on Funding and Finance for Wales (2010) Fairness and accountability: $a$ new funding settlement for Wales. Welsh Government, Cardiff.

Isebaert D., Heylen, F. and Smolders, C. (2011) Houses and/or Jobs: Ownership and the Labour Market in Belgian Districts. Forthcoming, Regional Studies

Landais C., Kleven H. J. and Saez E. (2013) Taxation and international mobility of superstars: evidence from the European football market, American economic review, 103(5): 1892-1924

Milligan K. and Smart M. (2013) The Devolution of the Revolution: Taxation of High Incomes in a Federation. Working Paper, University of Exeter Business School.

Mirrlees J., Adam S., Besley T., Blundell R., Bond S., Chote R., Gammie M., Johnson P., Myles G. and Poterba J. (2011) The Mirrlees Review: Conclusions and Recommendations for Reform, Fiscal Studies 32, 331-59.

Oates W. E. (1999) An essay on fiscal federalism, Journal of economic literature 37, 1120-49.

Oates W. E. (2005) Toward a second-generation theory of fiscal federalism, International Tax and Public Finance 12, 349-73.

OECD (2011) Divided we Stand: Why Inequality Keeps Rising. OECD, Paris.

Piketty T. and Saez E. (2006), The evolution of top incomes: a historical and international perspective. American Economic Review, Papers and Proceedings, 96 (2), 2006, 200-205

Portes, J. (2011) Poverty and Inequality: Introduction, National Institute Economic Review 218, R1.

Purvis, J. (2012) DevoPlus: A stronger Scotland within the UK. Devo Plus Group, Edinburgh.

Ratti C., Sobolevsky S., Calabrese F., Andris C., Reades J., Martino M., Claxton R. and Strogatz S. H. (2010) Redrawing the Map of Great Britain from a Network of Human Interactions, PLOS ONE 5(12): e14248. doi:10.1371/journal.pone.0014248.

Riley, R. (2013) Modelling demand for low skilled/low paid labour: exploring the employment tradeoffs of a living wage. National Institute for Economic and Social Research, London. 
Scottish Government (2013) Scotland's economy: the case for independence. Scottish Government, Edinburgh.

Social Mobility and Child Poverty Commission (2013) State of the Nation 2013: social mobility and child poverty in Great Britain. Social Mobility and Child Poverty Commission, London.

Stewart M. B. (2011) The changing picture of earnings inequality in Britain and the role of regional and sectoral differences, National Institute Economic Review 218, R20-32.

Stiglitz J. (2013) Inequality is a choice, New York Times.

Tiebout C. M. (1956) A pure theory of local expenditures, The journal of political economy 64, 41624.

Trench, A. (2013) Funding Devo More: fiscal options for strengthening the Union. IPPR, London.

Tselios V., Rodríguez-Pose A., Pike A., Tomaney J. and Torrisi G. (2012) Income inequality, decentralisation, and regional development in Western Europe, Environment and Planning-Part A 44, 1278.

Weingast B. R. (2009) Second generation fiscal federalism: The implications of fiscal incentives, Journal of Urban Economics 65, 279-93.

Whittaker,M. and Hurrell,A. (2013) Low Pay Britain 2013. Resolution Foundation, London. 